\title{
SISTEM INFORMASI MANAJEMEN SEBAGAI MEDIA PROMOSI \\ BAGI LEMBAGA PENDIDIKAN \\ OLEH \\ DARMAN
}

\begin{abstract}
Abstrak
Dalam memromosikan Lembaga pendidikan yang paling efektif adalah dengan melalui teknologi Informasi, Dalam era teknologi saat ini lembaga pendidikan harus mampu memromosikan diri agar dapat dikenal lebih luas oleh masyarakat. Dengan adanya system informasi manajemen lembaga pendidikan dapat bersaing, sehingga lembaga pendidikan dalam mempromosikan diri tidak terbatas ruang dan waktu. Sistem informasi dalam suatu pemahaman yang sederhana dapat didefinisikan sebagai satu sistem berbasis komputer yang menyediakan informasi bagi beberapa pemakai dengan kebutuhan yang serupa.

Promosi merupakan salah satu variabel di dalam marketing mix yang sangat penting dilaksanakan oleh perusahaan dalam pemasaran produk atau jasanya. Menurut Martin L. Bell dalam Basu Swasta dan Irawan (1990:349) promosi adalah semua jenis kegiatan pemasaran yang ditujukan untuk mendorong permintaan. Sedangkan menurut William G. Nikels dalam bukunya Basu Swasta dan Irawan (1990:349) promosi adalah arus informasi atau persuasi satu arah yang dibuat untuk mengarahkan seseorang atau organisasi kepada tindakan yang menciptakan pertukaran dalam pemasaran.
\end{abstract}

Kata Kunci: Sistem Informasi Manajemen, Promosi, Lembaga Pendidikan

\section{A. Pendahuluan}

Perkembangan Teknologi Informasi dan Komunikasi (TIK) sangat pesat di berbagai bidang. Demikian pula TIK dalam dunia pendidikan juga telah banyak dirasakan peran dan kemanfaatannya. Penggunaan TIK dalam penyelenggaraan dan pengelolaan pendidikan memberikan dukungan dan layanan informasi yang lebih baik secara internal dan eksternal. Perkembangan TIK telah mempengaruhi dua bagian penting dalam sistem Pendidikan yaitu manajemen dan aktivitas pembelajaran. Pemanfaatan TIK telah dan atau diharapkan akan meningkatkan efisiensi manajemen pendidikan dan meningkatkan efektifitas aktifitas pembelajaran yang keduanya merupakan kunci penting daya saing lembaga pendidikan dalam menghadapi persaingan global yang semakin ketat.

Mengingat lembaga pendidikan di Indonesia merupakan organisasi yang memiliki orientasi ganda (multiple oriented), yaitu organisasi yang berorientasi sosial dan orientasi bisnis. orientasi sosial pendidikan bertujuan meningkatkan kecerdasan 
bangsa sedangkan orientasi bisnis pendidikan dalam mempertahankan eksistensi maupun operasionalnya harus memiliki dana yang cukup memadai.

Dengan demikian, lembaga pendidikan tersebut akan menghasilkan lulusan (outcomes) yang berkualitas. Banyak bermunculan lembaga-lembaga pendidikan yang berani menetapkan biaya pendidikan cukup tinggi karena sarana dan prasarana belajar yang disediakan juga jauh lebih baik dan menjanjikan kepada para siswa maupun mahasiswa untuk ikut melakukan magang di perusahaan-perusahaan yang sudah terkenal. Dengan demikian, ada kemungkinan mereka yang berprestasi akan langsung direkrut oleh perusahaan tersebut. Oleh karena itu, masyarakat lebih banyak memilih lembaga pendidikan yang marketable maupun sellable walaupun harus mengeluarkan biaya sangat mahal. Gambaran sistem informasi pendidikan yang dibutuhkan di Indonesia idealnya adalah bagaimana para pengambil keputusan bidang pendidikan dapat dengan mudah mencari informasi sebagai bahan dalam proses pengambilan keputusan bidang pendidikan. Misalnya, berapa jumlah sumber daya manusia pendidikan yang dibutuhkan, jenis sekolah, tingkatan sekolah, pelaksanaan kurikulum, perkembangan lembaga pendidikan lokal, regional, nasional, bahkan internasional untuk dapat memperbaiki kinerja dunia pendidikan masa lalu, masa kini, maupun masa yang akan datang.

Dalam menghadapi globalisasi, dunia pendidikan Indonesia harus secepatnya berbenah diri dalam meningkatkan sistem informasi guna menunjang daya saing sumber daya manusia yang dihasilkan oleh lembaga pendidikan tersebut. Sistem informasi yang akan diciptakan harus seimbang antara infrastruktur teknologi yang tersedia dengan kemampuan sumber daya manusianya sehingga tidak terjadi ketimpangan yang sangat jauh, dan sistem informasi tidak dapat terwujud secara signifikan dalam menunjang kuantitas maupun kualitas pendidikan secara mendasar. Di samping itu, sistem informasi semakin dibutuhkan oleh lembaga pendidikan, khususnya dalam melakukan pengelolan dan promosi untuk meningkatkan kelancaran aliran informasi dalam lembaga pendidikan, kontrol kualitas, dan menciptakan aliansi atau kerja sama dengan pihak lain yang dapat meningkatkan nilai lembaga pendidikan tersebut.

\section{B. KONSEP PROMOSI}

Dalam mengelola suatu sistem komunikasi pemasaran memerlukan suatu rancangan strategi dan program-program penjualan yang efektif dan efisien. Promosi 
penjualan merupakan unsur kunci dalam kampanye perusahaan dan promosi yang paling baik adalah promosi yan dilakukan oleh pelanggan yang puas. Dengan demikian, promosi perlu ditangani secara cermat karena masalahnya bukan hanya menyangkut pada bagaimana berkomunikasi dengan pelanggan akan tetapi juga menyangkut seberapa besar biaya yang dikeluarkan untuk biaya ini yang tentunya harus disesuaikan pada kondisi dan kemampuan perusahan.

\section{Pengertian Promosi}

Promosi merupakan salah satu variabel di dalam marketing mix yang sangat penting dilaksanakan oleh perusahaan dalam pemasaran produk atau jasanya. Menurut Martin L. Bell dalam Basu Swasta dan Irawan (1990:349) promosi adalah semua jenis kegiatan pemasaran yang ditujukan untuk mendorong permintaan. Sedangkan menurut William G. Nikels dalam bukunya Basu Swasta dan Irawan (1990:349) promosi adalah arus informasi atau persuasi satu arah yang dibuat untuk mengarahkan seseorang atau organisasi kepada tindakan yang menciptakan pertukaran dalam pemasaran.

Kedua definisi tersebut pada pokoknya sama meskipun titik beratnya berbeda. Definisi pertama lebih menitik beratkan pada pendorongan permintaan. Sedangkan definisi kedua lebih menitik beratkan pada penciptaan pertukaran. Pertukaran akan terjadi karena adanya permintaan dan penawaran, dengan adanya permintaan akan mendorong terciptanya pertukaran. Jadi promosi merupakan salah satu aspek yang penting dalam manajemen pemasaran dan sering dikatakan sebagai proses berlanjut. Dengan promosi menyebabkan orang yang sebelumnya tidak tertarik untuk membeli suatu produk akan menjadi tertarik dan mencoba produk sehingga konsumen melakukan pembelian.

Jenis promosi atau promosional mix menurut William J. Stanton dalam Basu Swasta dan Irawan (1990:349) adalah kombinasi strategi yang paling baik dari variabel-variabel periklanan, personal selling, dan alat promosi yang lain, yang semuanya direncanakan untuk mencapai tujuan program penjulan. Definisi tersebut tidak menyebutkan secara jelas beberapa variabel promotion mix selain periklanan dan personal selling.

\section{Variabel-variabel Promosi}

Menurut Kotler \& Armstrong variabel-variabel yang ada di dalam promotional mix ada lima, yaitu: 
a) Periklanan (advertising)

Segala biaya yang harus dikeluarkan sponsor untuk melakukan presentasi dan promosi non pribadi dalam bentuk gagasan, barang atau jasa.

b) Penjualan Personal (personal selling)

Presentasi pribadi oleh para wiraniaga perusahaan dalam rangka mensukseskan penjualan dan membangun hubungan dengan pelanggan.

c) Promosi penjualan (sales promotion)

Insentif jangka pendek untuk mendorong pembelian atau penjualan suatu produk atau jasa.

d) Hubungan masyarakat (public relation)

Membangun hubungan baik dengan publik terkait untuk memperoleh dukungan, membangun "citra perusahaan" yang baik dan menangani atau menyingkirkan gosip, cerita dan peristiwa yang dapat merugikan.

e) Pemasaran langsung (direct marketing)

Komunikasi langsung dengan pelanggan yang diincar secara khusus untuk memperoleh tanggapan langsung.

Dengan demikian maka promosi merupakan kegiatan perusahaan yang dilakukan dalam rangka memperkenalkan produk kepada konsumen sehingga dengan kegiatan tersebut konsumen tertarik untuk melakukan pembelian.

\section{Tahap-tahap Pelaksanaan Promosi}

Pelaksanaan promosi akan melibatkan beberapa tahap (BasuSwasta Dh dan Irawan, 1990: 359-361), antara lain:

1) Menentukan Tujuan

Tujuan promosi merupakan awal untuk kegiatan promosi. Jika perusahaan menetapkan beberapa tujuan sekaligus, maka hendaknya dibuat skala prioritas atau posisi tujuan mana yang hendak dicapai lebih dulu.

2) Mengidentifikasi Pasar yang Dituju

Segmen pasar yang ingin dicapai oleh perusahaan dalam promosinya harus dapat dibatasi secara terpisah menurut faktor demografis dan psikografis. Pasar yang dituju harus terdiri atas individu-individu yang sekiranya bersedia membeli produk tersebut selama periode yang bersangkutan.

3) Menyusun Anggaran 
Anggaran promosi sangat penting untuk kegiatan-kegiatan perencanaan keuangan dari manajer pemasaran. Anggaran digunakan untuk mengarahkan pengeluaran uang dalam mencapai tujuan tersebut.

4) Memilih Berita

Tahap selanjutnya dimulai dengan berita yang tepat untuk mencapai pasar yang dituju tersebut. Sifat berita itu akan berbeda-beda tergantung pada tujuan promosinya. Jika suatu produk itu masih berada pada tahap perkenalan dalam siklus kehidupannya, maka informasi produk akan menjadi topik utama. Sedangkan pada tahap selanjutnya perusahaan lebih cenderung mengutamakan tema promosi yang bersifat persuasif.

5) Menentukan Promotional Mix

Perusahaan dapat menggunakan tema berita yang berbeda-beda pada masingmasing kegiatan promosinya. Misalnya, hubungan masyarakat dapat dilakukan untuk menciptakan kesan positif terhadap perusahaan diantara para pembeli. Periklanannya dapat dititik beratkan untuk memberikan kesadaran kepada pembeli tentang suatu produk atau perusahaan yang menawarkannya.

6) Memilih Media Mix

Media adalah saluran penyampaian pesan komersial kepada khalayak sasaran. Untuk alternatif media secara umum dapat dikelompokkan menjadi media cetak (surat kabar, majalah, tabloid, brosur, selebaran) media elektronik (Televisi , radio) media luar ruang (baleho, poster, spanduk, balon raksasa) media lini bawah (pameran, direct mail, point of purchase, kalender) dan Teknologi Informasi. Untuk itu manajer harus memilih media yang cocok untuk ditujukan pada kelompok sasaran produk perusahaan.

7) Mengukur Efektifitas

Pengukuran efektifitas ini sangat penting bagi manajer. Setiap alat promosi mempunyai pengukuran yang berbeda-beda, tanpa dilakukannya pengukuran efektifitas tersebut akan sulit diketahui apakah tujuan perusahaan dapat dicapai atau tidak.

8) Mengendalikan dan Memodifikasi Kampanye Promosi

Setelah dilakukan pengukuran efektifitas, ada kemungkinan dilakukan perubahan rencana promosi. Perubahan dapat terjadi pada promotional mix, media mix, berita, anggaran promosi, atau cara pengalokasian anggaran tersebut. Yang 
penting, perusahaan harus memperhatikan kesalahan-kesalahan yang pernah diperbuat untuk menghindari kesalahan yang sama di masa mendatang.

\section{SISTEM INFORMASI MANAJEMEN SEBAGAI MEDIA PROMOSI PENDIDIKAN}

\section{Konsep Sistem Informasi Manajemen}

Sistem informasi dalam suatu pemahaman yang sederhana dapat didefinisikan sebagai satu sistem berbasis komputer yang menyediakan informasi bagi beberapa pemakai dengan kebutuhan yang serupa. Para pemakai biasanya tergabung dalam suatu entitas organisasi formal, seperti Departemen atau Lembaga suatu Instansi Pemerintahan yang dapat dijabarkan menjadi Direktorat, Bidang, Bagian sampai pada unit terkecil dibawahnya.

Informasi menjelaskan mengenai organisasi atau salah satu sistem utamanya mengenai apa yang telah terjadi di masa lalu, apa yang sedang terjadi sekarang dan apa yang mungkin akan terjadi dimasa yang akan datang tentang organisasi tersebut.

Sistem informasi memuat berbagai informasi penting mengenai orang, tempat, dan segala sesuatu yang ada di dalam atau di lingkungan sekitar organisasi. Informasi sendiri mengandung suatu arti yaitu data yang telah diolah ke dalam suatu bentuk yang lebih memiliki arti dan dapat digunakan untuk pengambilan keputusan. Data sendiri merupakan faktafakta yang mewakili suatu keadaan, kondisi, atau peristiwa yang terjadi atau ada di dalam atau di lingkungan fisik organisasi. Data tidak dapat langsung digunakan untuk pengambilan keputusan, melainkan harus diolah lebih dahulu agar dapat dipahami, lalu dimanfaatkan dalam pengambilan keputusan. Informasi harus dikelola dengan baik dan memadai agar memberikan manfaat yang maksimal. Penerapan sistem informasi di dalam suatu organisasi dimaksudkan untuk memberikan dukungan informasi yang dibutuhkan, khususnya oleh para pengguna informasi dari berbagai tingkatan manajemen. Sistem informasi yang digunakan oleh para pengguna dari berbagai tingkatan manajemen ini biasa disebut sebagai: Sistem Informasi Manajemen.

Sistem informasi mengandung tiga aktivitas dasar di dalamnya, yaitu: aktivitas masukan (input), pemrosesan (processing), dan keluaran (output). Tiga aktivitas dasar ini menghasilkan informasi yang dibutuhkan organisasi untuk pengambilan keputusan, pengendalian operasi, analisis permasalahan, dan 
menciptakan produk atau jasa baru. Masukan berperan di dalam pengumpulan bahan mentah (raw data), baik yang diperoleh dari dalam maupun dari lingkungan sekitar organisasi. Pemrosesan berperan untuk mengkonversi bahan mentah menjadi bentuk yang lebih memiliki arti. Sedangkan, keluaran dimaksudkan untuk mentransfer informasi yang diproses kepada pihak-pihak atau aktivitasaktivitas yang akan menggunakan. Sistem informasi juga membutuhkan umpan balik (feedback), yaitu untuk dasar evaluasi dan perbaikan di tahap input berikutnya.

Dewasa ini, sistem informasi yang digunakan lebih berfokus pada sistem informasi berbasis komputer (computer-based information system). Harapan yang ingin diperoleh di sini adalah bahwa dengan penggunaan teknologi informasi atau sistem informasi berbasis komputer, informasi yang dihasilkan dapat lebih akurat, berkualitas, dan tepat waktu, sehingga pengambilan keputusan dapat lebih efektif dan efisien.

Meskipun sistem informasi berbasis komputer menggunakan teknologi komputer untuk memproses data menjadi informasi yang memiliki arti, ada perbedaan yang cukup tajam antara komputer dan program komputer di satu sisi dengan sistem informasi di sisi lainnya. Komputer dan perangkat lunak komputer yang tersedia merupakan fondasi teknis, alat, dan material dari sistem informasi modern. Komputer dapat dipakai sebagai alat untuk menyimpan dan memproses informasi. Program komputer atau perangkat lunak komputer merupakan seperangkat instruksi operasi yang mengarahkan dan mengendalikan pemrosesan informasi.

\section{Data, Informasi dan Pengetahuan}

a) Data adalah deskripsi tentang benda, kejadian, aktivitas, dan transaksi yang tidak mempunyai makna atau tidak berpengaruh secara langsung kepada pemakai. Data dapat berupa Data terformat, Text, Citra, Audio, Video.

b) Informasi adalah data yang telah diproses sehingga meningkatkan pengetahuan seseorang yang menggunakannya (McFadden, 1999). Jumlah ketidakpastian yang dikurang ketika sebuah pesan diterima (Kroenke, 1992)

Data yang telah diolah menjadi sebuah bentuk yang berarti bagi penerimanya dan bermanfaat dalam pengambilan keputusan (Davis, 1999)

Ciri-ciri informasi :

1. Benar atau salah 
Informasi berhubungan dengan kebenaran terhadap kenyataan

2. Baru

Informasi benar-benar baru bagi si penerima

3. Tambahan

Informasi dapat memperbaharui atau memberikan perubahan terhadap informasi yang telah ada

4. Korektif

Informasi dapat digunakan untuk melakukan koreksi terhadap informasi sebelumnya yang salah atau kurang benar

5. Penegas

Informasi dapat mempertegas informasi yang telah ada sehingga meningkatkan keyakinan terhadap informasi

Kualitas informasi merupakan bagian dari karakteristik informasi, diukur berdasarkan :

- relevansi

- $\quad$ ketepatan waktu

- keakurasian

c) Pengetahuan adalah kombinasi dari naluri, gagasan, aturan, dan prosedur yang mengarahkan tindakan atau keputusan (Alter, 1992)

Sistem informasi manajemen merupakan sebagai kumpulan dari interaksi sistem-sistem informasi yang bertanggung jawab mengumpulkan dan mengolah data untuk menyediakan informasi yang berguna untuk semua tingkatan manajemen di dalam kegiatan perencanaan dan pengendalian.

\section{Elemen-Elemen Sistem Informasi yang terdiri dari :}

1. Tujuan

Setiap sistem mempunyai tujuan yang menjadi pemotivasi arah sistem.

Tujuan utama sistem informasi :

- Mendukung fungsi kepengurusan manajemen

- Mendukung pengambilan keputusan

- Mendukung kegiatan operasi Menuju kepada keunggulan kompetitif (mampu bersaing)

2. Masukan (input). 
Segala sesuatu yang masuk ke dalam sistem dan selanjutnya menjadi bahan untuk diproses. Pada sistem informasi masukan dapat berupa data (transaksi/non-transaksi), dan atau instruksi

3. Proses

Merupakan bagian yang melakukan perubahan atau transformasi dari masukan menjadi keluaran. Pada sistem informasi proses dapat berupa meringkas data, melakukan penghitungan, mengurutkan data, dsb.

4. Keluaran

Merupakan hasil dari pemrosesan. Pada sistem informasi keluaran bisa berupa informasi, saran, cetakan laporan, dsb.

5. Mekanisme pengendalian dan Umpan balik

Mekanisme pengendalian diwujudkan dengan menggunakan umpan balik. Umpan balik ini digunakan untuk mengendalikan masukan maupun proses (dilakukan perbandingan antara keluaran sistem dengan keluaran yang dikehendaki/standar)

6. Batas

Pemisah antara sistem dan daerah di luar sistem (lingkungan) yang menentukan konfigurasi, ruang lingkup, atau kemampuan sistem. Batas sistem dapat dimodifikasi dan berpengaruh terhadap perubahan perilaku sistem.

Contoh : pertumbuhan penjualan dipengaruhi modal, gerakan pesaing, pembelian. Apabila saham dijual akan meningkatkan modal sehingga dapat mengubah perilaku sistem penjualan.

7. Lingkungan

Segala sesuatu yang berada di luar sistem dan dapat mempengaruhi operasi sistem. Lingkungan bagi sistem informasi dapat berupa vendor, pelanggan, pemilik, pemerintah, bahkan pesaing.

\section{Karakteristik sistem}

Suatu sistem mempunyai karakteristik. Karakteristik sistem adalah sebagai berikut :

1. Suatu sistem mempunyai komponen-komponen sistem atau subsistemsubsistem (components)

2. Suatu sistem mempunyai batas sistem (boundary)

3. Suatu sistem mempunyai lingkungan luar (environment)

4. Suatu sistem mempunyai penghubung atau antarmuka (interface) 
5. Suatu sistem mempunyai tujuan ( goal)

\section{Komponen Sistem Informasi}

1. Perangkat Keras (hardware) : Peranti fisik (komputer, printer)

2. Perangkat Lunak (software) : Program; sekumpulan perintah agar hardware dapat memproses data

3. Prosedur : Aturan yang digunakan untuk memproses data dan output yang diinginkan

4. Orang : Pihak yang bertanggungjawab dalam pengembangan sistem informasi, proses, penggunaan output

5. Basis Data : Sekumpulan tabel, link, dan lain2 yang berkaitan dengan penyimpanan data

6. Jaringan Komputer dan komunikasi data : Sistem penghubung yang memungkinkan resource diakses secara bersama.

\section{Tujuan Penggunaan Sistem Informasi dalam Promosi}

Tujuan menggunakan system informasi dalam promosi antara lain :

1. Menyediakan suatu informasi untuk pengambilan suatu keputusan.

2. Menyediakan suatu informasi yang dipergunakan didalam suatu perencanaan, pengendalian, pengevaluasian dan juga perbaikan berkelanjutan.

3. Menyediakan suatu informasi yang dipergunakan di dalam suatu perhitungan harga pokok produk, jasa dan tujuan lainnya yang diinginkan oleh manajemen.

Kelebihan Menggunakan Sistem Informasi dalam Pengelolan dan Promosi Lembaga Pendidikan antara lain :

1. Menyediakan komunikasi dalam organisasi atau antar organisasi yang murah, akurat dan cepat.

2. Menyimpan informasi dalam jumlah yang sangat besar dalam ruang yang kecil tetapi mudah diakses

3. Memungkinkan pengaksesan informasi yang sangat banyak di seluruh dunia dengan cepat dan murah

4. Meningkatkan efektivitas dan efisiensi orang-orang yang bekerja dalam kelompok dalam suatu tempat atau pada beberapa lokasi

\section{PENUTUP}


System informasi dapat digunakan dalam mempromosikan lembaga pendidikan/sekolah. Salah satu kelebihan dalam menggunakan system informasi adalah informasi yang disampaikan dapat di akses dari berbagai daerah atau Negara, dalam artian informasi yang ada disekolah atau lembaga pendidikan tidak terbatas ruang dan waktu.

Era teknologi saat ini informasi suatu lembaga pendidikan sangatlah penting untuk dipublikasikan kemasyarakat luas agar dapat dikenal lebih luas. Dalam hal keterbukaan informasi tentungya dibutuhkan keahlian dalam mengemabngan dan mengelola informasi, sehingga informasi yang disampaikan dapat dipahami oleh masyarakat.

\section{DAFTAR PUSTAKA}

Basu Swastha, DH dan Irawan. 1990. Manajemen Pemasaran Modern. Yogyakarta: Liberty.

Buku Tim Dosen Jurusan Administrasi Pendidikan, Pengelolaan Pendidikan..2007. UPI Bandung

Dasuqi, Dudung, A. dan Somantri, Setyo. (1992). Wawasan Dasar Pendidikan dan Wawasan Dasar Administrasi Pendidikan. Dalam Administrasi Pendidikan. Bandung: Jurusan Administrasi Pendidikan, Fakultas Ilmu Pendidikan IKIP Bandung.

Rifai M, Administrasi dan Supervisi Pendidikan, Bandung: Jenmars, 1982

Rochaety. Ety dkk, 2009. Sistem Informasi Pendidikan, Jakarta, Bumi Aksara.

Siagian, Sondang, P, 1983, Organisasi Kepemimpinan Dan Prilaku Administrasi, Gunung Agung, Jakarta.

Sutisna, Oteng. 1983. Administrasi Pendidikan Dasar Teoritis Untuk Praktek Profesional. Bandung: angkasa. 
